Syntax Literate: Jurnal Ilmiah Indonesia p-ISSN: 2541-0849

e-ISSN: 2548-1398

Vol. 6, No. 10, Oktober 2021

\title{
ANALISIS PROFITABILITAS BANK UMUM KONVENSIONAL SEBELUM DAN SAAT PANDEMI COVID-19
}

\section{Yufi Indah Hairunnisa, Sri Mulyantini, Jubaedah}

Universitas Pembangunan Nasional (UPN) Veteran Jakarta, Indonesia

Email: yufiindahh19@gmail.com, srimulyantini61@gmail.com,

jubaedah.nawir@gmail.com

\begin{abstract}
Abstrak
Penelitian ini bertujuan untuk mengetahui determinan profitabilitas bank umum konvensional sebelum pandemi dan saat pamdemi Covid-19 yang terdaftar di Bursa Efek Indonesia. Populasi dalam penelitian ini adalah seluruh bank umum konvensional yang terdaftar di Bursa Efek Indonesia (BEI) selama periode 20192020. Teknik pemilihan sampel yang digunakan yaitu sampling jenuh dan diperoleh sampel sebanyak 40 perusahaan. Teknik analisis data yang digunakan adalah analisis deskriptif menggunakan Microsoft Excel 2013 dan pengujian hipotesis dalam penelitian ini menggunakan Analisis Regresi Data Panel dengan program Eviews version 9.0. dan tingkat signifikansi 5\%. Hasil penelitian saat sebelum pandemi Covid-19 menunjukkan bahwa (1) Tingkat Kecukupan Modal (CAR) tidak berpengaruh terhadap profitabilitas (ROA), (2) Likuiditas (LDR) berpengaruh positif terhadap profitabilitas (ROA), (3) Efisiensi Operasional (BOPO) berpengaruh negatif terhadap profitabilitas (ROA). Sedangkan untuk hasil penelitian saat pandemi Covid-19 menunjukan bahwa (1) Tingkat Kecukupan Modal (CAR) tidak berpengaruh terhadap profitabilitas (ROA), (2) Likuiditas (LDR) tidak berpengaruh terhadap profitabilitas (ROA), (3) Efisiensi Operasional (BOPO) berpengaruh negatif terhadap profitabilitas (ROA).
\end{abstract}

Kata Kunci: profitabilitas; tingkat kecukupan modal; likuiditas; efisiensi operasional.

\section{Abstract}

This study aims to determine and analyze the profitability of conventional commercial banks before the pandemic and during the Covid-19 pandemic which are listed on the Indonesia Stock Exchange. The population in this study are all conventional commercial banks listed on the Indonesia Stock Exchange (IDX) during the 2019 - 2020 period. The sample selection technique used is saturated sampling and obtained a sample of 40 companies. The data analysis technique used is descriptive analysis using Microsoft Excel 2013 and hypothesis testing in the study using Panel Data Regression Analysis with the program E-views version 9.0. and a significance level of 5\%. The results of research before the Covid-19 pandemic showed that (1) Capital Adequacy Ratio (CAR) had no effect on profitability (ROA), (2) Liquidity (LDR) had a positive effect on profitability (ROA),

(3) Operational Efficiency (BOPO) had a negative effect on profitability (ROA). Meanwhile, the results of research during the Covid-19 pandemic show that (1)

$\begin{array}{lll}\text { How to cite: } & \text { Hairunnisa. Y. I., Mulyantini, E \& Jubaedah, J. (2021) Analisis Profitabilitas Bank Umum Konvensional } \\ & \text { Sebelum dan Saat Pandemi Covid-19. Syntax Literate: Jurnal Ilmiah Indonesia, 6(10). } \\ & \text { http://dx.doi.org/10.36418/ Syntax-Literate.v6i10.4355 } & \\ \text { E-ISSN: } & 2548-1398 \\ \text { Published by: } & \text { Ridwan Institute }\end{array}$


Capital Adequacy Ratio (CAR) has no effect on profitability (ROA), (2) Liquidity (LDR) has no effect on profitability (ROA), (3) Operational Efficiency (BOPO) has a negative effect on profitability (ROA)

Keywords: profitability; capital adequacy ratio; liquidity; operational efficiency

Received: 2021-09-20; Accepted: 2021-10-05; Published: 2021-10-20

\section{Pendahuluan}

Menurut (Siringoringo, 2012) bank merupakan sumber utama pembiayaan pada level mikro ekonomi, maka dari itu sangat penting bagi bank untuk terus dapat menjaga tingkat profitabilitasnya tetap stabil bahkan meningkat agar kepercayaan masyarakat untuk menyimpan di bank juga meningkat (Agustiningrum, 2013). dan juga kinerja keuangan perusahaan adalah salah satu dasar penilaian terhadap kondisi keuangan perusahaan yang dapat dilakukan berdasarkan analisis terhadap rasio-rasio keuangan perusahaan (Husnan \& Pamudji, 2013)

Akhir tahun 2019 menjadi awal adanya wabah virus penyakit yang menyerang warga dunia khususnya Indonesia, virus ini dinamakan Virus 2019nCov atau dengan istilah terbaru dinamakan Covid-19. Di dalam negeri kasus perdana Covid- 19 disampaiakan di tanggal 2 Maret 2020. Hal tersebut berdampak pada penurunan laba perbankan yang ada di Indonesia, hal itu di kemukakan oleh Otoritas Jasa Keuangan (OJK), yang mengatakan bahwa Otoritas Jasa Keuangan atau OJK memprediksi keuntungan bank sampai akhir tahun akan menurun sekitar 30\%-40\% dibandingkan dengan tahun sebelumnya. Penyusutan laba bank sudah nampak dari kuartal II 2020 (Fraser \& Ormiston, 2008). Selama April sampai Juni 2020, keuntungan perbankan sebelum pajak tercatat menurun 19,8\% dari tahun sebelumnya. Menurut Otoritas Jasa Keuangan (OJK) keuntungan perbankan sudah terkoreksi sejak kuartal pertama tahun 2020. Penurunan laba bank semakin bertambah sampai kuartal ketiga tahun 2020. Berdasarkan data OJK, per September 2020 laba bank merosot 27,6 \% secara year on year (yoy). Penurunan lab aitu kian dalam dibandingkan dengan posisi Agustus 2020 yang menyusut $18,26 \%$ (yoy). Ditengah penurunan profitabilitas, beban operasional terhadap pendapatan operasional per September 2020 naik menjadi 86,18\% dari bulan sebelumnya 85,09 \% (Abate \& Mesfin, 2019).

Menghadapi pandemi yang belum selesai ini, Lembaga Pemeringkat Internasional, Moody's Investors Service menurunkan prospek Bank Negara dari stabil menjadi negative dalam waktu 12 hingga 18 bulan. Ini bertepatan dengan ekonomi yang lemah. Tim analisis Moody's menjelaskan bahwa meskipun restrukturisasi dan penurunan suku bunga kredit dapat memberikan dukungan, kualitas kredit telah menurun. Meskipun begitu, dana bermodal tinggi tetap dapat memberikan dukungan atas risiko tinggi yang dihadapi saat ini (Al Hasny \& Oey, 2016).

Dalam tiga tahun terakhir, rasio kecukupan modal bank atau rasio CAR memang stabil di atas 20\%, lebih tinggi dari 16-17\% selama krisis keuangan global 2008. Pada Januari 2020, rasio kecukupan modal mendekati 23\%. Meski begitu, tekanan terhadap 
profitabilitas bank masih sulit dihindari (Ponco, 2008). Otoritas Jasa Keuangan (OJK) memprediksi pada akhir tahun ini laba bank akan turun sekitar 30\%-40\% dari tahun sebelumnya. Mulai kuartal kedua tahun 2020, kita bisa melihat depresiasi laba bank. Antara April 2020 dan Juni 2020, laba bank sebelum pajak tercatat turun 19,8\% dari tahun sebelumnya (Adam, Safitri, \& Wahyudi, 2018).

Turunnya laba ini dikarenakan banyaknya restrukturisasi kredit karena Covid- 19. Berdasarkan data Otoritas Jasa Keuangan, kredit macet bank terjadi kenaikan 3,22\%. Angka tersebut mengalami meningkat dari bulan Juni yang bernilai 3,1\%. Meskipun mengalami penurunan keuntungan dan meningkatnya kredit macet, akan tetapi data otoritas jasa keuangan menunjukkan bahwa likuiditas bank di Indonesia cukup memadai dalam menyalurkan kredit untuk mendorong pertumbuhan perekonomian. otoritas jasa keuangan mencatat sampai Agustus 2020, total alat Likuid (AL) bank menyentuh Rp.1.913 triliun. Itu berarti, sampai saat ini sektor jasa keuangan di Indonesia masih memadai baik dari segi permodalan ataupun likuiditas dalam penyaluran kredit ataupun pembiayaan yang dapat mendukung target pertumbuhan perekonomian (Putra, Merawati, \& Parenrengi, 2019).

Namun, dibalik tetap eksisnya industri perbankan secara keseluruhan di Indonesia, tidak semua bank memiliki kemampuan yang sama dalam menghadapi pandemi Covid19. Dari segi permodalan, bank dengan aset terbatas tidak memiliki modal yang besar. Dilihat dari proporsi Dana Pihak Ketiga (DPK), bank kecil hanya fokus pada beberapa deposan (Eng, 2013). Akibatnya, risiko likuiditas muncul karena penurunan rasio simpanan bank terhadap arus kas, yang dapat meningkat selama pandemi ini. Dampak Covid-19 terhadap likuiditas bank mudah dipengaruhi oleh bank yang tidak dikelola dengan baik. Tata kelola perusahaan yang baik dengan prinsip transparansi, akuntabilitas, tanggung jawab, kemandirian, dan kewajaran saat ini berada dalam era pandemi, apabila terjadi keterpurukan ekonomi nasional dapat meningkatkan fleksibilitas kondisi internal perbankan (Attar \& Islahuddin, 2014).

Terkait efisiensi perbankan, belum ada yang memprediksi wabah Covid-19 akan menyebabkan kondisi perekonomian atau industri perbankan terpuruk, meski demikian masih ada harapan untuk pertumbuhan yang positif. Sejak April 2020 hingga Agustus 2020, pemerintah, BI, OJK, dan LPS terus mengeluarkan insentif, melonggarkan kebijakan, dan menggunakan kewenangannya untuk menjaga stabilitas dan meningkatkan kinerja bank (Dewi, Cipta, \& Kirya, 2015).

Berdasarkan Bank Indonesia penurunan profitabilitas ini disebabkan oleh sentimen meningkatnya jumlah kasus pemularan Covid-19 di Indonesia, dimana profitabilitas ini sangat penting bagi perusahaan, karena tingkat pendapatan diguakan untuk mengukur efektivitas manajemen perusahaan yang diperoleh dari penjualan dan pendapatan investasi (Darmawi, 2012). Disamping itu bank juga wajib melihat tingkat kecukupan modal yang cukup agar mampu melindungi suatu perbankan Ketika mengalami kerugian yang tidak terduga. Selain itu juga dalam kegiatan perbankan, pengelolaan likuiditas juga merupakan masalah yang kompleks, dimana kemampuan bank dalam mengelola likuiditas akan memengaruhi kepercayaan masyarakat terhadap 
bank itu sendiri, sehingga mendorong keberlangsungan operasional dan kelangsungan hidup bank (Fahmi, 2014). Selain memperhatikan rasio kecukupan modal dan likuiditas, perbankan juga perlu memperhatikan efisiensi operasional, sebab efisiensi merupakan parameter untuk menghitung kinerja keseluruhan dari aktivitas suatu perusahaan, dimana jika efisiensi dikelola dengan baik akan meningkatkan kinerja perusahaan dan meningkatkan profit atau laba.

\section{Metode Penelitian}

Penelitian ini bersifat kausal yang bertujuan untuk mengetahui peranan variabel independen dalam memengaruhi variabel dependen. Jenis penelitian ini dipilih karena tujuan penelitian adalah untuk menjelaskan hubungan dan pengaruh yang terjadi antar variabel. Penelitian ini menggunakan metode analisis kuantitatif sebagai metode analisisnya yang merupakan analisis yang menggunakan angka-angka dan perhitungan.

Variabel pada penelitian ini dibedakan menjadi dua yaitu variabel dependen dan variabel independen. Variabel dependen (terikat) adalah variabel yang nilainya tergantung dari nilai variabel lain (Y) dan variabel independen (bebas) adalah variabel yang nilainya tidak tergantung pada variabel lain $(X)$. jenis data yang digunakan pada penelitian ini adalah data sekunder, yaitu data yang diperoleh secara tidak langsung dari sumber pertama perusahaan. Data sekunder dari bank umum yang terdaftar pada Bursa Efek Indonesia (BEI). Data yang digunakan adalah data laporan keuangan triwulan untuk periode 2019-2020. Dan dalam penelitian ini sampel yang digunakan adalah sampling jenuh (Nafi, 2020).

Data yang digunakan dalam penelitian ini data panel. Data panel adalah data yang memiliki jumlah cross section dan jumlah time series. Data dikumpulkan dalam suatu rentan waktu terhadap banyak individu. Tahap analisis yang dilakukan dalam penelitian ini menggunakan alat bantu perangkat lunak pengelolaan data Econometric Views (EViews) yang merupakan salah satu aplikasi olah data statistika dan ekonometrika. Dalam penelitian ini peneliti menggunakan program Eviews version 9.

Berikut adalah definisi dan pengukuran variabel operasional yang digunakan ini:

1. Variabel Dependen (Y) : Profitabilitas

Profitabilitas diukur dengan return on asset (ROA), dimana ROA merepresentasikan kemampuan perusahaan menggunakan seluruh asetnya untuk menghasilkan laba setelah pajak. Return on Asset (ROA) digunakan sebagai indikator kinerja atau kinerja bank, berdasarkan pertimbangan berikut: ROA meliputi kemampuan seluruh elemen aset bank yang digunakan untuk menghasilkan pendapatan.

$$
\text { ROA }=\frac{\text { Laba Setelah Pajak }}{\text { Total Aset }} \times 100 \%
$$

2. Variabel Independen (X):

a. Tingkat Kecukupan Modal (X1) 
Sesuai dengan ketentuan Bank Indonesia modal minimum yang harus dimiliki bank adalah $8 \%$. Perhitungan rasio permodalan ini menggunakan ATMR (Aset Tertimbang Menurut Risiko) yang bertujuan untuk mengubah rasio aset berbasis risiko sehingga tercipta sistem perbankan yang lebih aman.

$$
\mathrm{CAR}=\frac{\text { Modal }}{\text { Aset Tertimbang Menurut Risiko }} \times 100 \%
$$

b. Likuiditas (X2)

LDR mengacu pada rasio kredit yang diberikan kepada pihak ketiga dalam rupiah dan valuta asing (tidak termasuk kredit yang diberikan kepada bank lain) dan dana pihak ketiga termasuk giro, tabungan, dan simpanan dalam rupiah dan valuta asing.

Jika bank dapat memandu kredit secara maksimal dan menjaga tingkat LDR dalam batas aman $80-92 \%$, maka profitabilitas yang direalisasikan akan maksimal.

$$
\text { LDR }=\frac{\text { Jumlah Kredit }}{\text { Dana Pihak Ketiga }} \times 100 \%
$$

c. Efisiensi Operasional (X3)

Semakin kecil rasionya maka semakin efektif biaya operasional yang dikeluarkan bank, sehingga masalah bank mungkin kecil. Bank Indonesia menetapkan rasio BOPO tidak boleh lebih dari 90\%, jika melebihi $90 \%$ bank tersebut tergolong tidak efisien.

$$
\mathrm{BOPO}=\frac{\text { Biaya Operasional }}{\text { Pendapatan Operasional }} \times 100 \%
$$

\section{Hasil dan Pembahasan}

\section{A. Statistik Deskriptif}

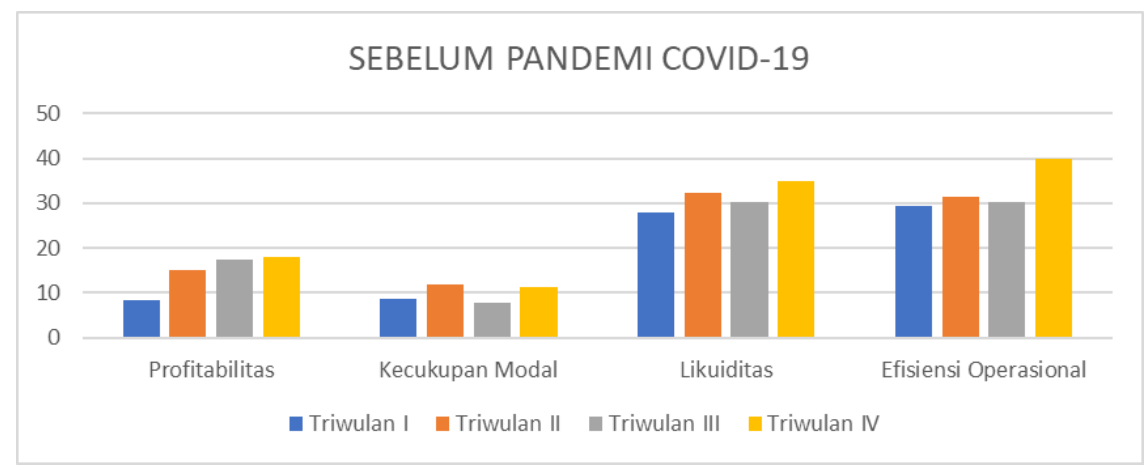

\section{Gambar 1}

Grafik Data Sebelum Pandemi Covid-19

Sumber : data diolah 
Berdasarkan data grafik diatas dapat disimpulkan variabel dependen dan independen sebelum pandemi Covid-19 tahun 2019 periode Triwulan I sampai dengan Triwulan IV, memiliki angka persentase pada variabel Profitabilitas perusahaan perbankan umum Triwulan I sebesar 8,26\%, Triwulan II sebesar 14,96\%, Triwulan III sebesar 17,37\% dan Triwulan IV sebesar 18,12\%. Adapun persentase pada variabel Kecukupan Modal perusahaan perbankan umum Triwulan I sebesar $8,67 \%$, Triwulan II sebesar $11,8 \%$, Triwulan III sebesar 7,93\% dan Triwulan IV sebesar 11,23\%. Lalu persentase pada variabel Likuiditas perusahaan perbankan umum Triwulan I sebesar 28\%, Triwulan II sebesar 32,31\%, Triwulan III sebesar 30,14\% dan Triwulan IV sebesar 35,01\%. Sedangkan persentase data terakhir pada variabel Efisiensi Operasional perusahaan perbankan umum Triwulan I sebesar 29,35\%, Triwulan II sebesar 31,35\%, Triwulan III sebesar 30,38\% dan Triwulan IV sebesar $39,77 \%$.

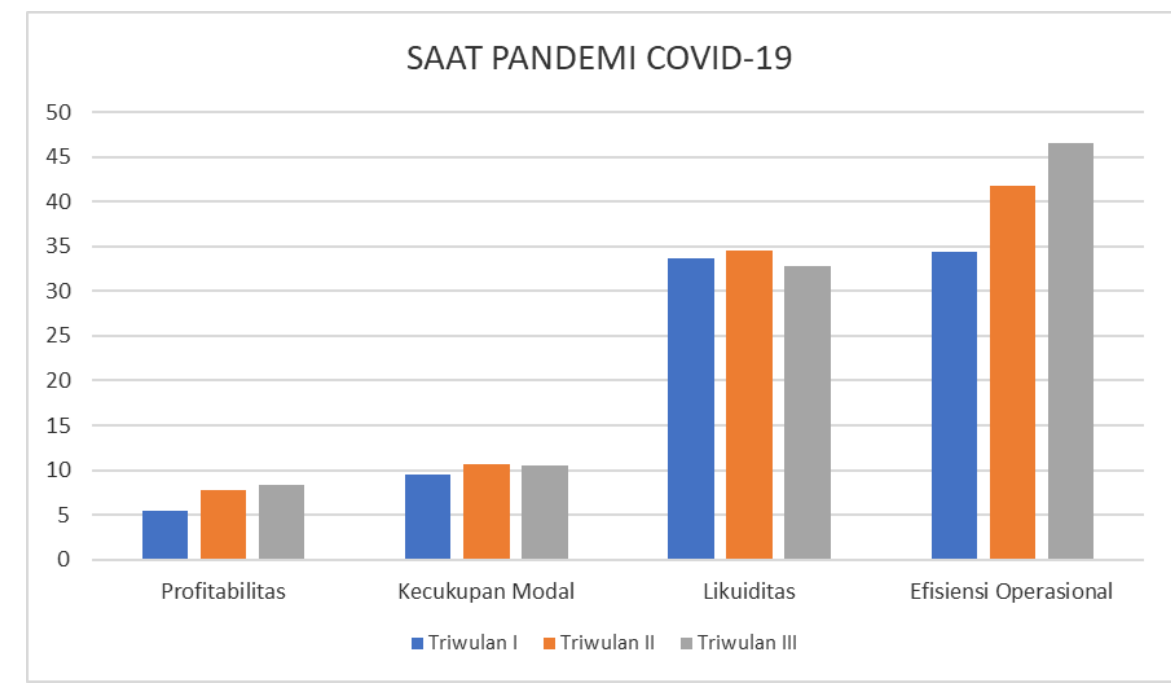

Gambar 2

Grafik Data Saat Pandemi Covid-19

Sumber : data diolah

Berdasarkan data grafik diatas dapat disimpulkan variabel dependen dan independen saat pandemi Covid-19 tahun 2020 periode Triwulan I sampai dengan Triwulan III, memiliki angka persentase pada variabel Profitabilitas perusahaan perbankan umum Triwulan I sebesar 5,48\%, Triwulan II sebesar 7,79\%, dan Triwulan III sebesar $8,31 \%$. Adapun persentase pada variabel Kecukupan Modal perusahaan perbankan umum Triwulan I sebesar 9,44\%, Triwulan II sebesar 10,66\%, danTriwulan III sebesar 10,53\%. Lalu persentase pada variabel Likuiditas perusahaan perbankan umum Triwulan I sebesar 33,63\%, Triwulan II sebesar $34,48 \%$, dan Triwulan III sebesar 32,86\%. Sedangkan persentase data terakhir pada variabel Efisiensi Operasional perusahaan perbankan umum Triwulan I sebesar $34,47 \%$, Triwulan II sebesar 41,80\%, dan Triwulan III sebesar 46,63\%. 


\section{B. Analisis Hipotesis dan Teknik Uji}

1. Pemilihan Metode Analisis:

a. Uji Chow

Uji chow (uji F restricted) dilakukan untuk menentukan model mana yang paling cocok untuk digunakan antara common effect model dan fixed effect model. Hipotesis dalam uji chow (uji batas F) adalah sebagai berikut:

$\mathrm{H} 0=$ Common Effect Model

H1 = Fixed Effect Model

Berdasarkan asumsi di atas, jika nilai probabilitas hasil cross sectional chi-square lebih besar dari 0,05 maka $\mathrm{H} 0$ diterima dan $\mathrm{H} 1$ ditolak yang berarti metode estimasi menggunakan model Common Effect. Sedangkan jika nilai probabilitas hasil uji cross sectional chi-square kurang dari 0,05 maka H0 ditolak dan H1 diterima yang berarti digunakan model Fixed Effect untuk teknik estimasi. Berikut adalah hasil uji chow atau uji $\mathrm{F}$ restricted:

\section{Tabel 1}

Hasil Uji Chow

\begin{tabular}{ccc}
\hline & Sebelum Pandemi Covid-19 & Saat Pandemi Covid-19 \\
\cline { 2 - 3 } Cross-section Chi-Square & 0,0000 & 0,0000 \\
\hline
\end{tabular}

Sumber: data diolah, Eviews 9.0

Dapat disimpulkan dari tabel diatas bahwa nilai probabilitas Crossssection Chi-Square sebelum dan saat pandemi Covid-19 pada penelitian ini adalah 0.0000 dan lebih kecil dari 0.05, sehingga $\mathrm{H} 0$ ditolak dan $\mathrm{H} 1$ diterima. Oleh karena itu berdasarkan uji chow (uji F terbatas), dalam model common effect model dan fixed effect model yang paling cocok untuk digunakan diantara model efek adalah fixed effect model.

b. Uji Hausman

Uji Housman digunakan untuk melihat model mana yang lebih baik antara fixed effect model dan random effect model. Hipotesis yang digunakan dalam uji housman adalah sebagai berikut:

$\mathrm{HO}=$ Fixed Effect Model

$\mathrm{H} 1=$ Random Effect Model

Berdasarkan asumsi diatas, jika nilai probabilitas hasil pengujian leih besar dari 0.05 maka $\mathrm{H} 0$ diterima dan $\mathrm{H} 1$ ditolak yang berarti digunakan model Random Effect Model (REM) untuk teknik estimasi. Sedangkan jika nilai probabilitas random cross section hasil pengujian lebih kecil dari 0,05 maka H0 ditolak dan H1 diterima yang berarti digunakan model fixed effect model (FEM) untuk teknik estimasi. Berikut adalah hasil uji housman: 


\section{Tabel 2}

Hasil Uji Housman

\begin{tabular}{lcc}
\hline & Sebelum Pandemi Covid-19 & Saat Pandemi Covid-19 \\
\cline { 2 - 3 } Cross-section random & 0,0134 & 0,0009 \\
\hline
\end{tabular}

Sumber: data diolah, Eviews 9.0

Berdasarkan tabel diatas, pada penelitian ini nilai probabilitas random cross section sebelum pandemi Covid-19 adalah 0,0134 dan saat pandemi Covid-19 adalah 0,0009 yang lebih kecil dari 0.05, maka H0 diterima dan H1 ditolak. Oleh karena itu model terbaik yang digunakan dalam penelitian ini adalah Fixed Effect Model. Dapat dikatakan bahwa model panel Uji Housman pada penelitian ini menggunakan model FEM (Fixed Effect Model).

2. Pengujian Hipotesis

a. Uji Uji T (Parsial)

Pengujian hipotesis menggunakan uji t bertujuan untuk mengetahui pengaruh variabel independen yaitu Tingkat Kecukupan Modal (X1), Likuiditas (X2) dan Efisiensi Operasional (X3) terhadap variabel dependen yaitu Profitabilitas (Y). Koefisien regresi parsial diuji hubungannya dengan keseluruhan variabel independen dalam uji ini. Dalam pengujian ini t hitung setiap koefisien regresi dibandingkan dengan nilai t table atau nilai kritis sesuai dengan tingkat signifikan yang ditentukan yaitu $\alpha=5 \%$.

Hipotesis dalam uji $\mathrm{t}$ dapat diukur dengan membandingkan nilai probabilitas < nilai kritis atau nilai probabilitas < 0.05 , maka $\mathrm{HO}$ ditolak dan $\mathrm{H}_{\mathrm{a}}$ diterima dan jika nilai probabilitas $>$ nilai kritis atau nilai probabilitas $>0.05$, maka $\mathrm{H} 0$ diterima dan $\mathrm{H}_{\mathrm{a}}$ ditolak.

Pengambilan hipotesis dalam uji t dapat diukur dengan membandingkan nilai $t_{\text {hitung }}$ dan $t_{\text {tabel }}$. Nilai $t_{\text {tabel }}$ dapat dilihat pada tabel statistik pada signifikasi 0.05 dengan derajat $\mathrm{df}=$ jumlah observasi $(\mathrm{N})-$ jumlah variabel $(\mathrm{k})$.

Tabel 3

Tabel Uji T (Parsial)

\begin{tabular}{lllll}
\hline & \multicolumn{2}{l}{ Sebelum Pandemi Covid-19 } & \multicolumn{2}{c}{ Saat Pandemi Covid-19 } \\
\cline { 2 - 5 } & Coefficient & Prob & Coefficient & Prob \\
\hline CAR & -0.001992 & 0.1902 & 0.005441 & 0.4140 \\
\hline LDR & 0.014999 & 0.0000 & -0.000692 & 0.8252 \\
\hline BOPO & -0.013141 & 0.0000 & -0.004422 & 0.0002 \\
\hline
\end{tabular}

Sumber: data diolah, Eviews 9.0

1) Pengaruh Tingkat Kecukupan Modal terhadap Profitabilitas.

Berdasarkan hasil regresi data panel, dapat dijelaskan sesuai dengan hasil uji t sebesar -1,317669 dan probabilitas sebesar 0,1902 yang lebih besar dari tingkat signifikasi yaitu 0.05. Dapat disimpulkan tingkat kecukupan modal sebelum pandemi Covid-19 tidak berpengaruh terhadap profitabilitas. 
Arah dari hubungan variabel kecukupan modal terhadap profitabilitas sebelum pandemi Covid-19 adalah negatif, Hal tersebut mengindikasikan bahwa modal sendiri bank tidak dioperasionalkan secara optimal, sehingga beban bank meningkat dengan menanggung biaya dana yang besar. Hasil penelitian ini sejalan dengan penelitian yang dilakukan oleh Purwoko \& Sudiyatno (2013) dan Jufriadi \& Rasyid (2019) yang menyatakan bahwa permodalan tidak berpengaruh terhadap kinerja bank. Capital Adequacy Ratio (CAR) menunjukan kemampuan permodalan bank dalam menjaga kemungkinan timbulnya risiko kerugian kegiatan usahanya, namun pengaruh yang diberikan ternyata tidak signifikan terhadap kinerja bank. Hal ini terjadi karena peraturan Bank Indonesia yang mengharuskna menjaga agar Capital Adequacy Ratio (CAR) minimal 8\%, sehingga para pemilik bank menambah modal bank yang berupa fresh money hanya agar Capital Adequacy Ratio (CAR) dapat memenuhi syarat yang ditetapkan Bank Indonesia dan tidak berusaha agar modal tersebut mampu memberi pengaruh signifikan terhadap kinerja bank.

Berdasarkan hasil regresi data panel, dapat diketahui bahwa sesuai dengan hasil uji t sebesar 0,821394 dan probabilitas sebesar 0,4140 yang lebih besar dari tingkat signifikasi yaitu 0.05. Dapat disimpulkan tingkat kecukupan modal sesudah pandemi Covid-19 tidak berpengaruh positif terhadap profitabilitas.

Arah dari hubungan variabel kecukupan modal terhadap profitabilitas saat pandemi Covid-19 adalah positif, menyiratkan bahwa kecukupan modal (CAR) berbanding lurus dengan profitabilitas bank (ROA), dimana jika CAR semakin tinggi maka memperkuat kemampuan bank untuk menanggung risiko setiap kredit dan meningkatkan profitabilitas bank (ROA Hasil penelitian ini sejalan dengan penelitian Ramadhanti, dkk (2019) dan Ngumo, dkk (2020) yang menyatakan bahwa semakin besar tingkat kecukupan modal maka semakin tinggi kemampuan permodalan bank dalam menjaga kemungkinan timbulnya risiko kerugian kegiatan usahanya, sehingga kinerja bank akan meningkat.

2) Pengaruh Likuiditas terhadap Profitabilitas.

Berdasarkan hasil regresi data panel, dapat dilihat dengan hasil uji $\mathrm{t}$ sebesar 7.79274 dan probabilitas sebesar 0,0000 yang lebih kecil dari tingkat signifikasi yaitu 0.05. Dapat disimpulkan likuiditas sebelum pandemi Covid-19 berpengaruh positif terhadap profitabilitas.

Arah dari hubungan variabel likuiditas terhadap profitabilitas sebelum pandemi Covid-19 adalah positif, artinya bahwa likuiditas (LDR) berbanding lurus dengan profitabilitas (ROA), semakin tinggi LDR maka laba bank semakin meningkat. Hal ini menunjukan bahwa kinerja bank dalam menyalurkan kredit kepada pihak ketiga cukup efisien. Semakin banyak kredit yang disalurkan, maka pendapatan yang diterima oleh bank 
akan meningkat seiring meningkatnya profitabilitas. Hal tersebut sesuai dengan teori yang dinyatakan oleh (Taswan, 2010 hlm. 167). Hasil penelitian ini didukung oleh penelitian terdahulu yang dilakukan oleh Abate \& Mesfin (2019) serta Ramadhanti,dkk (2019) yang menyatakan semakin tinggi rasio LDR menunjukkan semakin banyak jumlah dana pihak ketiga yang disalurkan dalam bentuk kredit. Ini akan memberikan lebih banyak pendapatan bunga yang akan meningkatkan profitabilitas.

Berdasarkan hasil regresi data panel, diketahui hasil uji t sebesar 0,221680 dan probabilitas sebesar 0,8252 yang lebih besar dari tingkat signifikasi yaitu 0.05. Dapat disimpulkan likuiditas sesudah pandemi Covid19 tidak berpengaruh terhadap profitabilitas.

Arah hubungan variabel likuiditas terhadap profitabilitas saat pandemi Covid-19 adalah negatif, artinya semakin tinggi LDR maka mengakibatkan semakin rendah profitabilitas (ROA). Hal ini menunjukan bahwa kinerja bank dalam menyalurkan kredit kepada pihak ketiga tidak efisien dengan baik. Hasil penelitian ini didukung oleh peneliti terdahulu yang dilakukann oleh Janrosl \& Yuliani (2017) serta Katarina, dkk (2020) yang menyatakan setiap kenaikan LDR yang berarti jumlah kredit yang disalurkan lebih besar dari pada dana pihak ketiga yang dihimpun dengan asumsi jumlah kredit macetnya akan meningkat sehingga kondisi bank tidak likuid dalam memenuhi kewajibannya, hal ini akan diikuti oleh penurunan ROA.

3) Pengaruh Efisiensi Operasional terhadap Profitabilitas

Berdasarkan hasil regresi data panel sebelum pandemi Covid-19, dapat dikahui hasil uji t sebesar -12,277 dan probabilitas sebesar 0,0000 yang lebih kecil dari tingkat signifikasi yaitu 0.05. Dapat disimpulkan efisiensi operasional sebelum pandemi Covid-19 berpengaruh negatif terhadap profitabilitas.

Dan berdasarkan hasil regresi data panel saat pandemi Covid-19, dapat dilihat hasil uji t sebesar -3,9533 dan probabilitas sebesar 0,0002 yang lebih kecil dari tingkat signifikasi yaitu 0.05. Dapat disimpulkan efisiensi operasional saat pandemi Covid-19 berpengaruh negatif terhadap profitabilitas.

Arah dari hubungan variabel efisiensi operasional terhadap profitabilitas saat sebelum dan saat pandemi Covid-19 adalah negatif, artinya tingkat efisiensi bank dalam menjalankan operasinya, berpengaruh terhadap tingkat pendapatan yang dihasilkan oleh bank. Apabila biaya yang dikeluarkan untuk kegiatan operasional dikelola dengan efisien maka pendapatan yang dihasilkan dari kegiatan operasional bank tersebut akan naik. Sehingga semakin meningkat rasio Beban Operasional Pendapatan Operasional (BOPO), maka akan semakin menurun kinerja keuangan perbankan dan sebaliknya, apabila rasio Beban Operasional Pendapatan Operasional (BOPO) semakin menurun, maka kinerja keuangan suatu 
perbankan semakin meningkat. Hal tersebut karena dengan memperkecil biaya operasional bank akan mempengaruhi tingkat profitabilitas bank yang tercermin dalam ROA sebagai indikator yang mencerminkan efektivitas perusahaan dalam menghasilkan laba dengan memanfaatkan keseluruhan aktiva yang dimiliki. Hasil penelitian ini didukung oleh penelitian terdahulu yang dilakukan oleh Jufriadi \& Rasyid (2019) serta Aditya, dkk (2019) yang menyatakan bahwa semakin tinggi nilai BOPO yang dimiliki sebuah bank akan semakin menurunnya kemampuan bank dalam menghasilkan laba serupa dengan hal tersebut dapat dikatakan pula bahwa dengan meningkatnya BOPO pada bank menandakan perusahaan lebih banyak mengeluarkan biaya operasional dalam menghasilkan keuntungan.

b. Koefisien Determinasi (Uji R2)

Hasil pengujian signifikasi ditunjukan pada tabel berikut:

Tabel 4

Hasil Pengujian Signifikansi

\begin{tabular}{ccccccc}
\hline & \multicolumn{2}{c}{ Sebelum Pandemi Covid-19 } & \multicolumn{3}{c}{ Saat Pandemi Covid-19 } \\
\hline Variabel & Koefisien & t-Statistik & Prob & Koefisien & t-Statistik & Prob \\
\hline ROA & 0.258681 & 1.721583 & 0.0878 & 0.553011 & 2.011405 & 0.0478 \\
\hline CAR & -0.001992 & -1.721583 & 0.1902 & 0.005441 & 0.821394 & 0.4140 \\
\hline LDR & 0.014999 & 7.7792748 & 0.0000 & -0.000692 & -0.221680 & 0.8252 \\
\hline BOPO & -0.013141 & -12.27730 & 0.0000 & -0.004422 & -3.953358 & 0.0002 \\
\hline Adj. $\boldsymbol{R}-$ & & 0,799301 & & & 0,726150 & \\
Square & & & & & & \\
\hline Prob (F- & & 0.000000 & & & 0.000000 & \\
Statistik) & & & & & & \\
\hline
\end{tabular}

Sumber: data diolah, Eviews 9.0

1) Persamaan regresi sebelum pandemi Covid-19 $\mathrm{Y}=0,258681-0,001992 \mathrm{CAR}+0,014999 \mathrm{LDR}-0,013141 \mathrm{BOPO}$

a) Konstanta sebesar 0,258681 artinya jika X1 (CAR), X2 (LDR), X3 (BOPO) nilainya adalah 0 , maka besarnya $\mathrm{Y}$ (ROA) nilainya sebesar 0,258681 .

b) Koefisien regresi variabel X1 (CAR) -0,0019 artinya setiap peningkatan X1 sebesar 1 satuan, maka akan menurunkan Y (ROA) sebesar 0,0019 satuan, regresi variabel X2 (LDR) 0,014 artinya setiap peningkatan X2 sebesar 1 satuan, maka akan meningkatkan Y (ROA) sebesar 0,014 satuan, Koefisien regresi variabel X3 (BOPO) -0,013 artinya setiap peningkatan $\mathrm{X} 3$ sebesar 1 satuan, maka akan menurunkan $\mathrm{Y}$ (ROA) sebesar 0,013 satuan, dengan asumsi variabel independen lain nilainya tetap.

2) Persamaan regresi saat pandemic Covid-19

$\mathrm{Y}=0,553011+0,005441 \mathrm{CAR}-0,000692 \mathrm{LDR}-0,004422 \mathrm{BOPO}$ 
a) Konstanta sebesar 0,553011 artinya jika X1 (CAR), X2 (LDR), X3 (BOPO) nilainya adalah 0 , maka besarnya $\mathrm{Y}$ (ROA) nilainya sebesar 0,553011 .

b) Koefisien regresi variabel X1 (CAR) 0,005441 artinya setiap peningkatan $\mathrm{X} 1$ sebesar 1 satuan, maka akan meningkatkan Y (ROA) sebesar 0,005441 satuan, Koefisien regresi variabel X2 (LDR) -0,000692 artinya setiap peningkatan $\mathrm{X} 2$ sebesar 1 satuan, maka akan menurunkan Y (ROA) sebesar -0,000692 satuan, Koefisien regresi variabel X3 (BOPO) -0,004422 artinya setiap peningkatan X3 sebesar 1 satuan, maka akan menurunkan Y (ROA) sebesar 0,004422 satuan,dengan asumsi variabel independen lain nilainya tetap.

Berdasarkan tabel 4, nilai Adjusted R-square sebelum pandemi Covid-19 adalah sebesar 0,799301 angka tersebut memberikan arti bahwa 79\% ROA dapat dijelaskan atau dipengaruhi oleh variabel independen, sedanglan sisanya $21 \%$ ditentukan oleh faktor-faktor lainnya diluar variabel. Dan nilai Adjusted R-square saat pandemi Covid19 adalah sebesar 0.726150 angka tersebut memberikan arti bahwa $72 \%$ ROA dapat dijelaskan atau dipengaruhi oleh ketiga variabel independen sedangkan sisanya $28 \%$ ditentukan oleh faktor-faktor lainnya diluar tingkat kecukupan modal, likuiditas dan efisiensi operasional terhadap profitabilitas.

\section{Kesimpulan}

Berdasarkan hasil penelitian dan pengujian hipotesis melalui analisis regresi data panel pada pembahasan bab 4, maka kesimpulan yang dapat ditarik sebagai berikut: 1). Variabel kecukupan modal yang diukur dengan Capital Adequacy Ratio (CAR) menunjukan hasil yang menyatakan bahwa kecukupan modal (CAR) sebelum dan saat pandemi Covid-19 tidak berpengaruh terhadap profitabilitas. 2). Variabel likuiditas yang diukur dengan Loan to Deposit Ratio (LDR) menunjukkan bahwa likuiditas (LDR) sebelum pandemi Covid-19 berpengaruh positif terhadap profitabilitas. Dan Variabel likuiditas (LDR) saat pandemi Covid-19 menunjukkan hasil tidak berpengaruh terhadap profitabilitas. 3). Variabel efisiensi operasional yang diukur dengan Biaya Operasional Pendapatan Operasional (BOPO) menunjukkan hasil yang menyatakan bahwa efisiensi operasional (BOPO) sebelum dan saat pandemi Covid-19 berpengaruh negatif terhadap profitabilitas. 


\section{BIBLIOGRAFI}

Abate, Tadesse Wubie, \& Mesfin, Enyew Alemaw. (2019). Factors Affecting Profitability Of Commercial Banks In Ethiopia. International Journal Of Research And Analytical Reviews, 6(1), 881-891. Google Scholar

Adam, Mohamad, Safitri, Riska, \& Wahyudi, Tertiarto. (2018). Effect Of Company Size, Liquidity And Operational Efficiency On Bank Profitability With Problem Credit Risk As A Moderating Variable At Commercial Banks That Are Listed On The Indonesia Stock Exchange. Jurnal Perspektif Pembiayaan Dan Pembangunan Daerah, 6(3), 331-344. Google Scholar

Agustiningrum, Riski. (2013). Analisis Pengaruh Car, Npl, Dan Ldr Terhadap Profitabilitas Pada Perusahaan Perbankan. Udayana University. Google Scholar

Al Hasny, Ayik Muh, \& Oey, Christin Berlinhan. (2016). Analisis Pengaruh Kecukupan Modal, Efisiensi Operasional Dan Likuiditas Terhadap Profitabilitas Bank Bumn Di Bursa Efek Indonesia Periode 2009-2013. Kajian Bisnis Sekolah Tinggi Ilmu Ekonomi Widya Wiwaha, 24(1), 11-24. Google Scholar

Attar, Dini, \& Islahuddin, M. Shabri. (2014). Pengaruh Penerapan Manajemen Risiko Terhadap Kinerja Keuangan Perbankan Yang Terdaftar Di Bursa Efek Indonesia. Jurnal Administrasi Akuntansi: Program Pascasarjana Unsyiah, 3(1). Google Scholar

Darmawi, Herman. (2012). Manajemen Perbankan Cet. 2. Bumi Aksara: Jakarta. Google Scholar

Dewi, Ni Kadek Venimas Citra, Cipta, Wayan, \& Kirya, I. Ketut. (2015). Pengaruh Ldr, Lar, Der Dan Cr Terhadap Roa. E-Journal Bisma Universitas Pendidikan Ganesha. Volume. Google Scholar

Eng, Tan Sau. (2013). Pengaruh Nim, Bopo, Ldr, Npl \& Car Terhadap Roa Bank Internasional Dan Bank Nasional Go Public Periode 2007-2011. Jurnal Dinamika Manajemen, 1(3). Google Scholar

Fahmi, Irham. (2014). Pengantar Perbankan Teori Dan Aplikasi. Bandung: Alfabeta. Google Scholar

Fraser, Lyn M., \& Ormiston, Aileen. (2008). Memahami Laporan Keuangan. Google Scholar

Husnan, Ahmad, \& Pamudji, Sugeng. (2013). Pengaruh Corporate Social Responsibility (Csr Disclosure) Terhadap Kinerja Keuangan Perusahaan. Fakultas Ekonomika Dan Bisnis. Google Scholar

Nafi, Faiz Anas. (2020). Pengaruh Resiko Kredit, Likuiditas, Kecukupan Modal Dan Efisiensi Operasional Terhadap Profitabilitas. Ummagelang Conference Series, 
345-355. Google Scholar

Ponco, Budi. (2008). Analisis Pengaruh Car, Npl, Bopo, Nim Dan Ldr Terhadap Roa (Studi Kasus Pada Perusahaan Perbankan Yang Terdaftar Di Bursa Efek Indonesia Periode 2004-2007). Program Pascasarjana Universitas Diponegoro. Google Scholar

Putra, Aditiya Ghanang Setiyadi, Merawati, Endang Etty, \& Parenrengi, Sudarmin. (2019). Analisis Pengaruh Kecukupan Modal, Likuiditas, Kualitas Aktiva, Efisiensi Operasional, Dan Rentabilitas Terhadap Profitabilitas. Jurnal Riset Manajemen Dan Bisnis (Jrmb) Fakultas Ekonomi Uniat, 4(S1), 697-708. Google Scholar

Siringoringo, Renniwaty. (2012). Karakteristik Dan Fungsi Intermediasi Perbankan Di Indonesia. Buletin Ekonomi Moneter Dan Perbankan, 15(1), 61-83. Google Scholar

\section{Copyright holder:}

Yufi Indah Hairunnisa, Sri Mulyantini, Jubaedah (2021)

First publication right:

Syntax Literate: Jurnal Ilmiah Indonesia

This article is licensed under: 